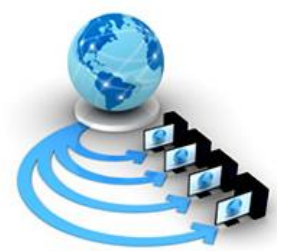

Volume 9, No. 4, July - August 2018

\title{
DESIGN AND DEVELOPMENT OF APBD (INDONESIAN LOCAL GOVERNMENT DISTRICT ANNUAL BUDGET) INFORMATION SYSTEMS ANALYSIS APPLICATION
}

\author{
Assistriadi Widjiseno \\ Informatics Engineering Program, \\ Kahuripan University Kediri \\ Indonesia
}

\author{
Joko Triono \\ Informatics Management Studies Program, \\ University of Merdeka Madiun \\ Indonesia
}

\begin{abstract}
A fundamental problem when conducting an analysis to determine dimension of local budget proportion allocations prioritized for public services improvement and economic fulfillment, people'ssocial, and cultural rights in the city's/regency's APBD document is amount of data and information to be processed,budget complexity,data structure as well as presentation format of information allocation andlimited budget distribution. Therefore, it is necessary to have a support from information technology as its solution, in which this information technology has been tested its capability and reliability in processing and utilizing available data in large quantity, fast, and various. This research aims to make ERD (entity relationship diagram)design, Data Flow Diagram (DFD) and APBD analysis information system application creation, that this application able to facilitate documentation process of APBD budget data which then processed into information or knowledge and produce output in the form of clustering analysis visualization or comparison analysis proportion of budget allocation based on fiscal year, city / regency, organizational code, income account code, shopping account code, finance account code, program account code, activity account code, bill account code and nominal budget. That visualization of this cluster will be become valuable information and knowledge for strengthening literacy capacity and analysis in the process of deliberation and stipulation of transparent and accountable APBD
\end{abstract}

Keywords: Information System, ERD, DFD, APBD, Accountable

\section{INTRODUCTION}

\section{Local Budgets Accountability Conception}

In Minister of Home Affairs Regulation Number 13 of 2006 concerning Guidelines on Regional Financial Management, it is mentioned that Local Government Revenue and Expenditure Budget, hereinafter referred to as APBD is the annual financial plan of local government discussed and approved jointly by the local government and DPRD, and stipulated by local regulations. Basic concept of APBD in framework of good governance is a Citizen Political Mandate on public resources that mandated to local government institutions (executive and legislative) as the owner of budget management authority. Thus, APBD is one of basic components of public policy that must be managed based on values of citizens' interests in order to achieve people's welfare. Therefore, in the of Minister of Home Affairs Regulation Number 13 of 2006 concerning Guidelines on Regional Financial Management, it is stated that Local Government Revenue and Expenditure Budget has an allocation function, meaning that regional budgets should be directed to create employment or reduce unemployment and reduce resources dissipation, also increase economy efficiency and affectivity.And the distribution function implies that local government budget policy should pay attention to sense of justice and propriety. In addition, within framework policy of local government budget not only macroeconomic issues (fiscal and monetary) but also social policy issues, including Public Services, Regulation, Development, and Empowerment.

As one of economics'resources and instruments of local government to implement its policies and work plan and have to be able to accommodate many interests, thus process of regional budgeting is loaded with various problems such as:

a) Implementation of performance budgeting has not been fully realized

b) Transparency and accessibility of information are still not fully open

c) Public participation room for involvement in supervision of regional budgeting policy is still low

d) Capacity and capability of human resources of city's/regency's DPRD members in APBD discussion and supervisionare generally still low

e) Draft framing time that is often delayed which every year is found in various regions that are slow in preparing budget of his government

f) Budget deficit occurs because government's revenue budget is unable to cover its spending budget

g) Government budget is less favorable to public interest

h) Inadequate public control functions to ensure that government budgeting process is in line with their expectations

So if regional budgeting process's various problems that mention above arenot immediately reduced or improved, it will cause ofbudget function failure impact or budget deficiencies such as:

a) Increasing corruption opportunities

b) Increasing social gaps and social unrest

c) Declining quality of public services

d) Snatching of citizens' basic rights

e) Decreasing people welfare

The consequences of such budget divergence will be dimensionally very complex that cover social, economics, psychology to political sphere. Socially Corruption has direct impact to degradation of regional development 
quality, decreasing quality of public services, public distrust toward government credibility [1] [2].

\section{Urgency of Information System Analysis Development of APBD}

One of problem that arises when conducting an analysis to determine ideal proportion of local budget allocations prioritized for public services improvement and economic fulfillment, social, and cultural rights of the people in City's/Regency's APBD document is data size and information that should be processed, budget data complexity structure as well as information allocation presentation format and limited budget distribution. Therefore, it is necessary to have information technology support as its solution, in which this information technology has been tested has capability and reliability in processing and utilizing available data in large volume, fast, and various [5] [6] [7].

\section{METHODOLOGY}

Research methodology that is used in this research will be divided into several stages. The stages are used to facilitate and answer problems that have been described previously. The steps that will be done in this research are as follows:

\section{A. Literature Study}

At this literature study stage aims to be able to clarify research problems and conduct an in-depth and critical evaluation about research topic design and manufacture of this APBD's Information Systems analysis, so based on research topics above then it need a reference that discusses about:

a) Regulation of Regional Planning and Budgeting Process

b) Local Budget Management Regulation

c) Regulation of City's/Regency's DPRD Role and Position

d) Regulation of APBD Document Structure

\section{B. Observation and Consultation}

Furthermore, to gain a comprehensive understanding from various parties that directly involved in local's planning and budgeting process, then at this stage required a series of observation and consultation, And with this stage, it will be able to catch a case of an information system usage from a functional point of view, which in this stage can generate scenarios to provide an understanding of reasons why problem that need to be resolved is feasible and important to be made its information system, and also it can provide a comprehensive picture. As for research methodology that used in this study, it will be divided into several stages. The stages are used to facilitate and answer the problems that have been described previously. The steps that will be done in this research are as follows:
a) Planning process and budgeting in SKPD
b) Planning process and budgeting in DPRD
c) Need analysis and system information designing

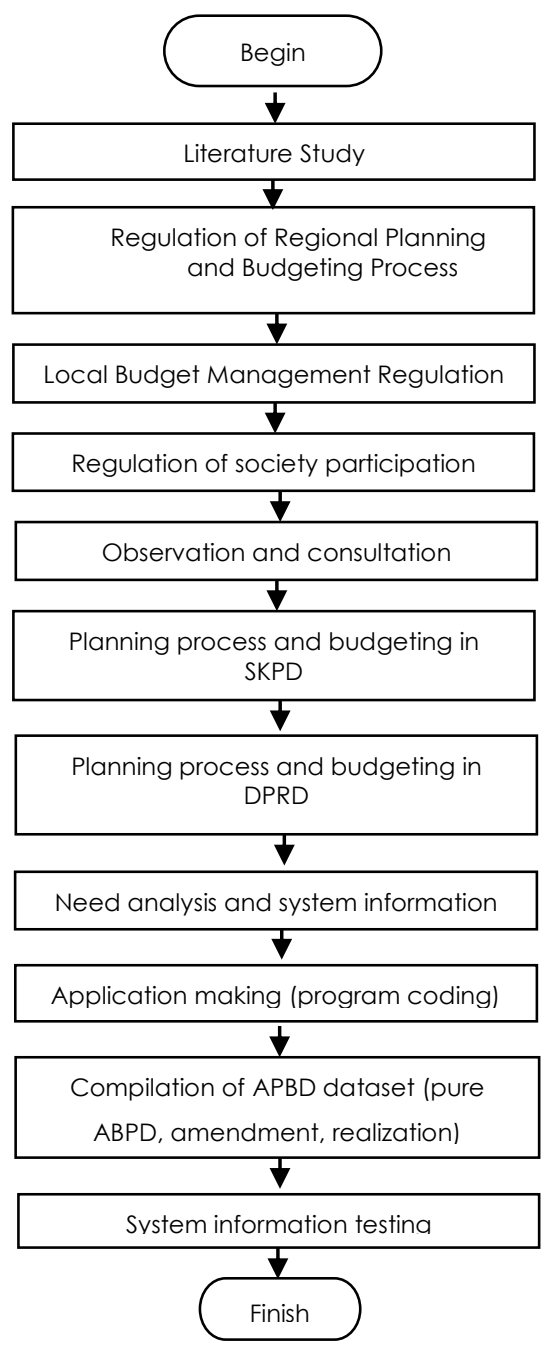

Figure 1 Research Methodology

\section{Need Analysis and System Designing}

Activity at this stage is to perform an analysis to determine specification of application need that requiresto make application design. This process is done by collecting data based on mechanism, procedure and regulation of APBD arrangement and then transformed as needspecification.And it proceed with application design making that includes design using model analysis in the form of database design, process design and user interface design that can represent application as needed. Approach that used in database design and process design is a structured approach in the form of data flow diagrams (DFD) and entity relationship diagrams (ERD) where this method of analysis is a classical method that use notation to describe information content and its flow, that is by dividing system in functional and its behavior, then describes what must be built.

\section{Application Making}

Next in this phase algorithms will be designed and application will be made (Coding Language Programming) based on software requirements specifications that have been produced in previous stages. 


\section{E. Compilation of APBD Dataset}

After application of this information system completed in coding process, then next step is to make data of Entry Budget APBD and Data Verification Budget of APBD document. Purpose of this process is to obtain a compilation of APBD dataset that will be used for system testing.

\section{F. System Testing}

Furthermore, in this stage carried out a series of information system testing by evaluating visualization output that generated by information system with data budget contained in APBD documents, if there is still incompatibility with data on budget data of APBD documents it is necessary to improve both in terms of algorithms or coding program.

\section{RESULT AND DISCUSSION}

\section{A. Data of APBD Budget Structure}

Based on Minister of Home Affairs Regulation Number 13 of 2006 on Guidelines of Regional Financial Management in Article 22, structure of APBD documents is broadly divided into 3 sections or code of account that is Regional Revenue, Regional Expenditure and Regional Financing as can be seen in Figure 1 below:

a) Regional revenue

Regional revenue includes all receipts of money through regional public treasury account, which adds equity funds, it is a regional right within a budget year and is not required to be repaid by local government and specified according to local government affairs, organization, group, type, object and details of income object.

b) Regional expenditure

Regional expenditures that cover all expenditures of regional general treasury accounts that reduce equity funds, are regional obligations within a fiscal year and will not be reimbursed by local government and specified according to local government affairs, organizations, programs, activities, groups, types, objects and details of shopping objects.

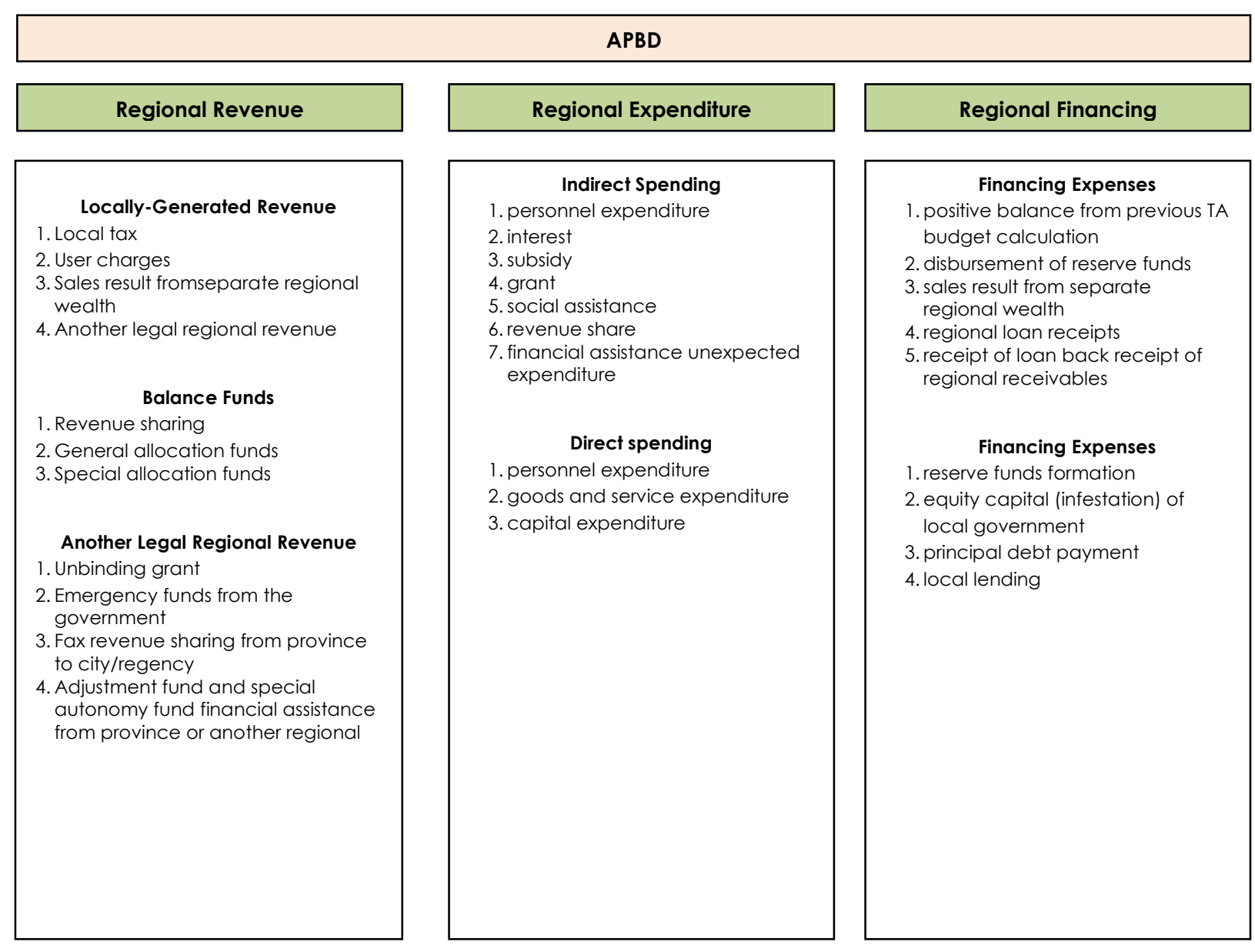

Figure 2 APBD structure 
c) Regional financing

It is all receipts that need be repaid and / or expenditures that need to be reimbursed, either in relevant fiscal year or in next fiscal years.

\section{B. Budget Data Format On APBD Documents}

While format of budget data writing contained in the APBD documents are as follows:

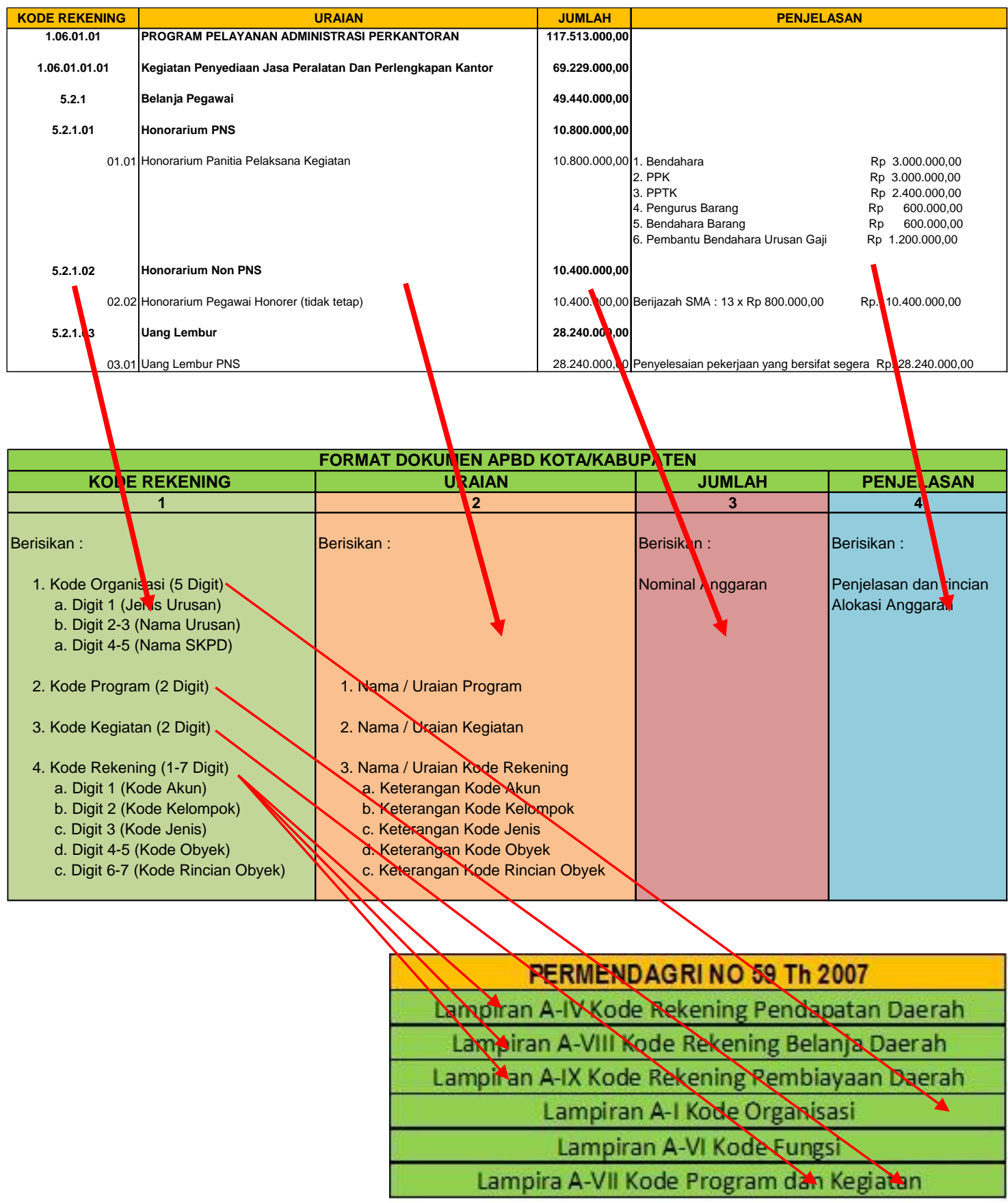

Figure 3 Budget Data Format on APBD Documents

\section{Organization Code Data Structure}

That based on illustration from picture above, it shows that budget data structure on the city / regency APBD document consists of 4 codes, they are organizational code, program code, activity code and account code. Data structure details from those four codes are as follows: first, the code of organization refers to the Annex A-I Permendagri No. 59 Th
2007, where that code consists of 5 digits with following composition: 


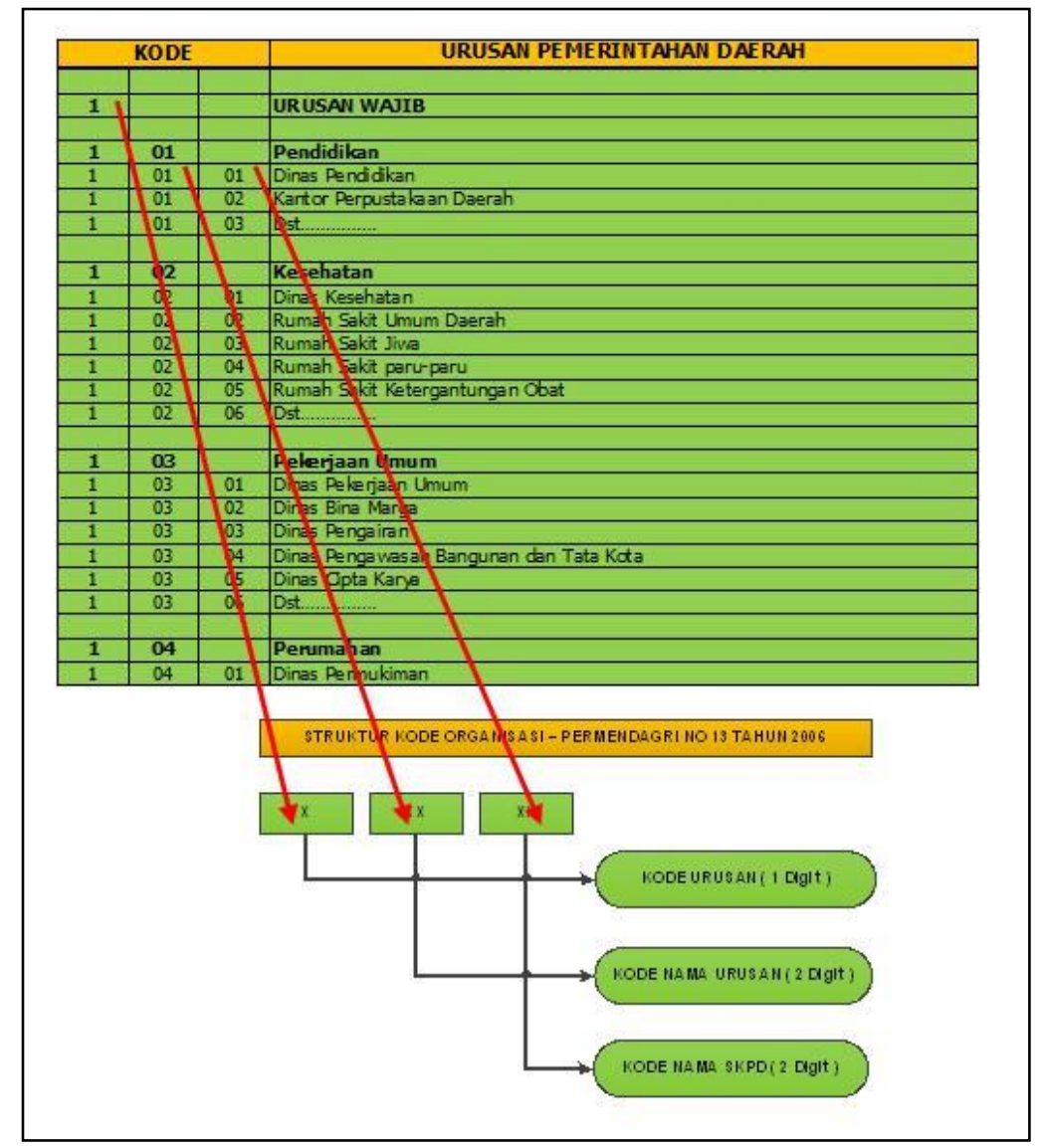

Figure 4 Organization Code Data Structure

\section{Data Structure Program Code And Activities}

Data structure code of program and activity refers to appendix A-VII Permendagri No 13 year of 2006, where this code consists of 4 digits with 2-digit composition for program code and 2 digits for activity code [4].

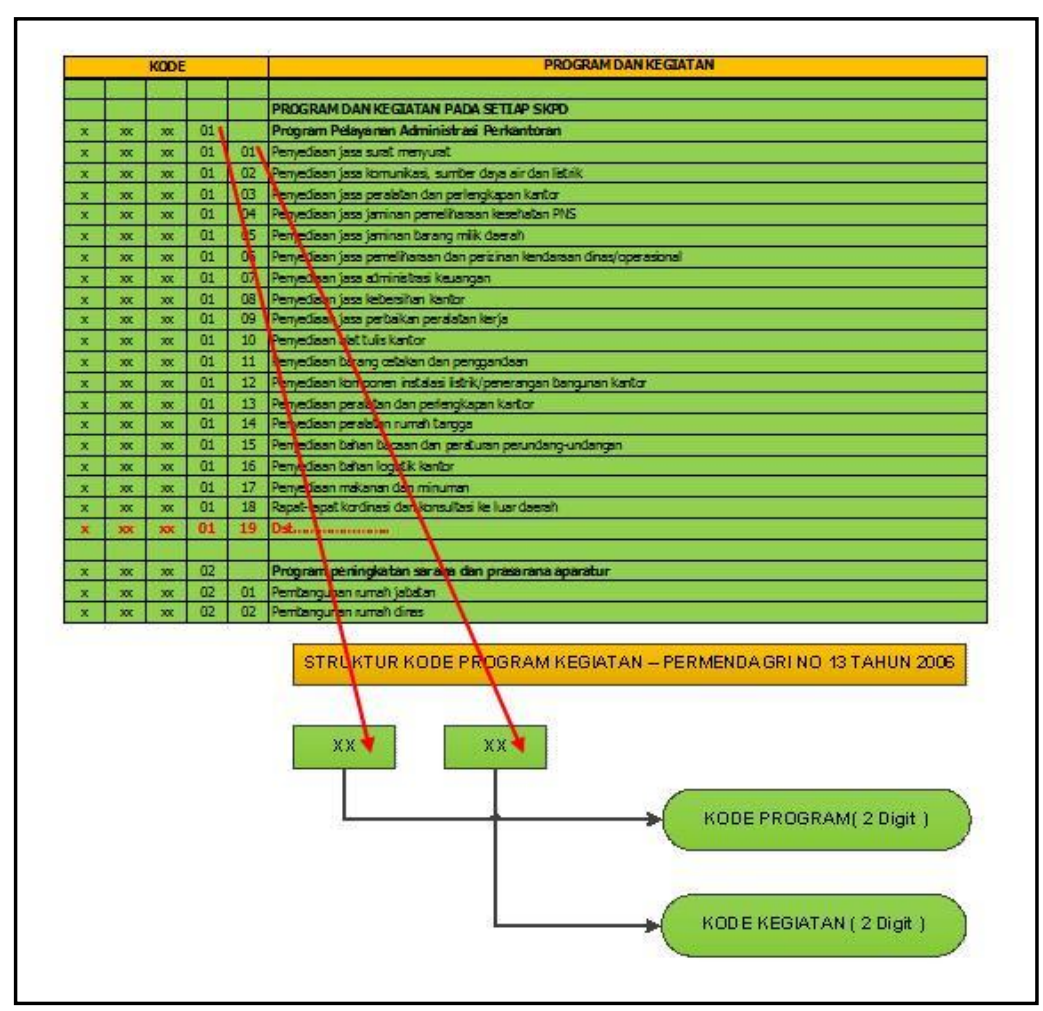

Figure 5 Data Structure Program Code and Activities 


\section{E. Account Code Data Structure}

The data code structure refers to Permendagri No. 59

Th 2007 Appendix A-IV for income account code,
Appendix A-VIII for shopping account code, Appendix AIX for account code of financing. In which for this account code consists of 7 digits with following composition [4].

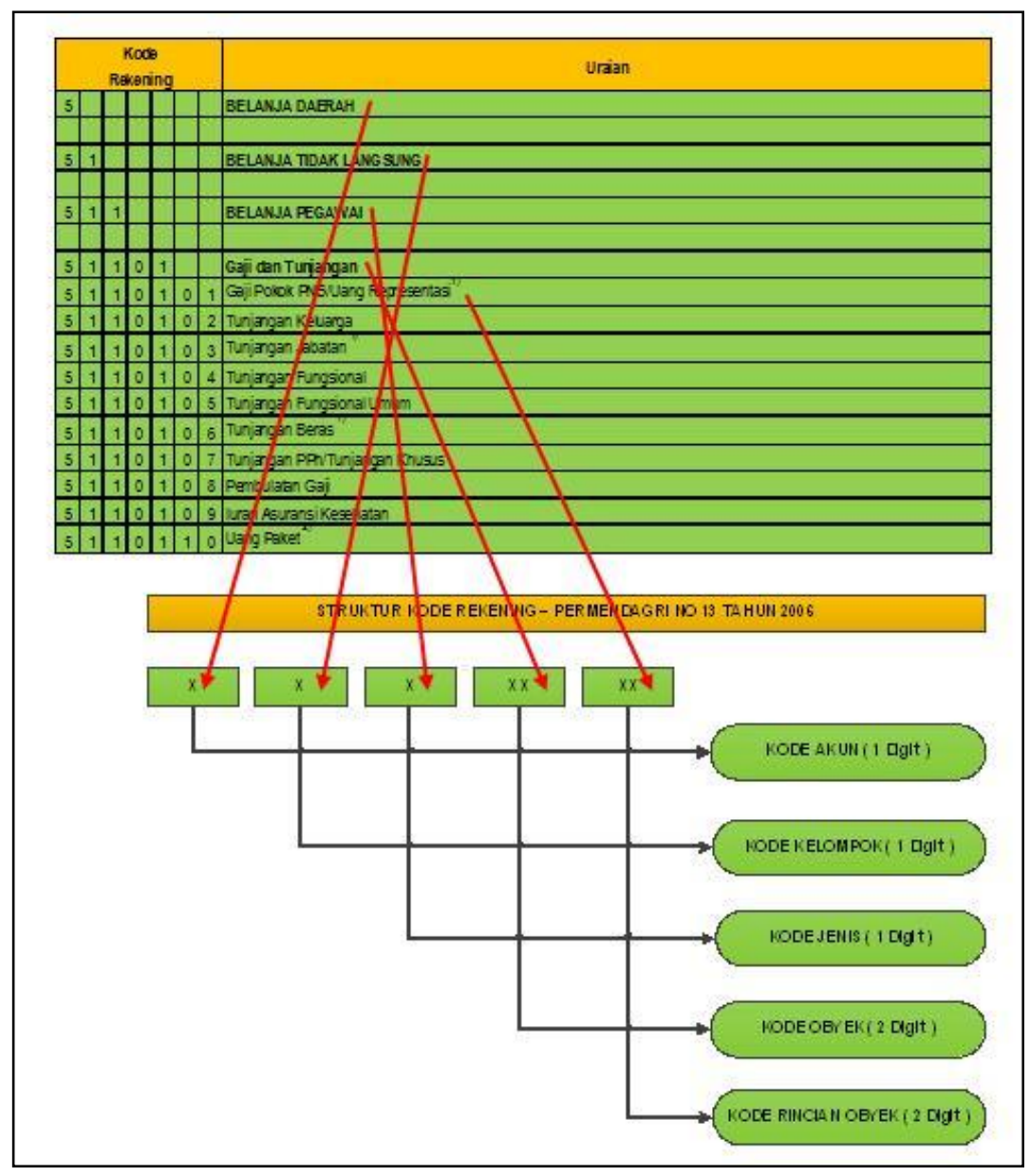

Figure 6 Account Code Data Structure

\section{F. ERD (Entity Relationship Diagram) Designing}

Design of APBD information system analysis application consisting of 7 entities that is APBD, aktivitas, dokumen, wilayah, SKPD, rekening, and analisis . As seen in figure 7.

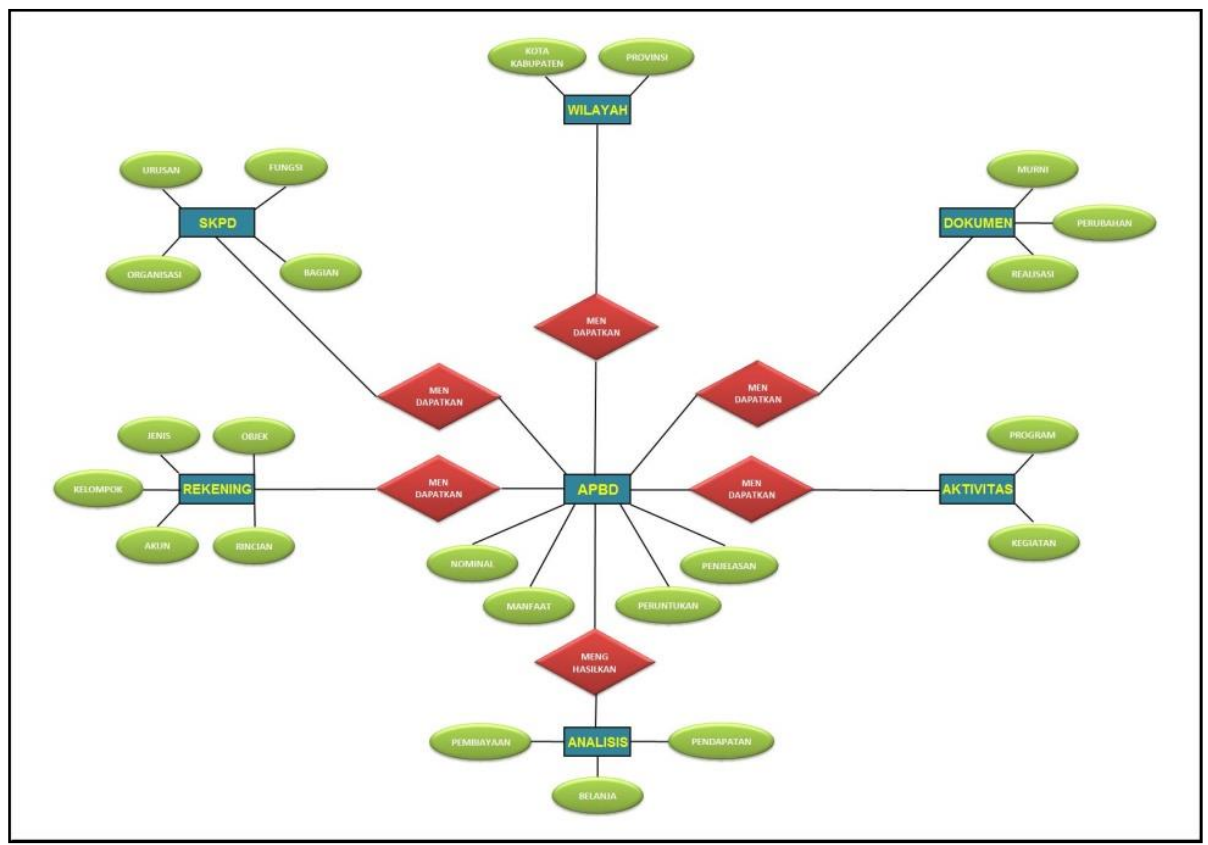

Figure 7 ERD (Entity Relationship Diagram) 


\section{G. DFD (Data Flow Diagram) Designing \\ DFD Level 0}

In Figure 8 below, it can be explained that Data Flow Diagram on this system using 3 entities, they are Budget
Council DPRD City / Regency and Administrator IT of DPRD City / Regency and Member DPRD City / Regency [3].

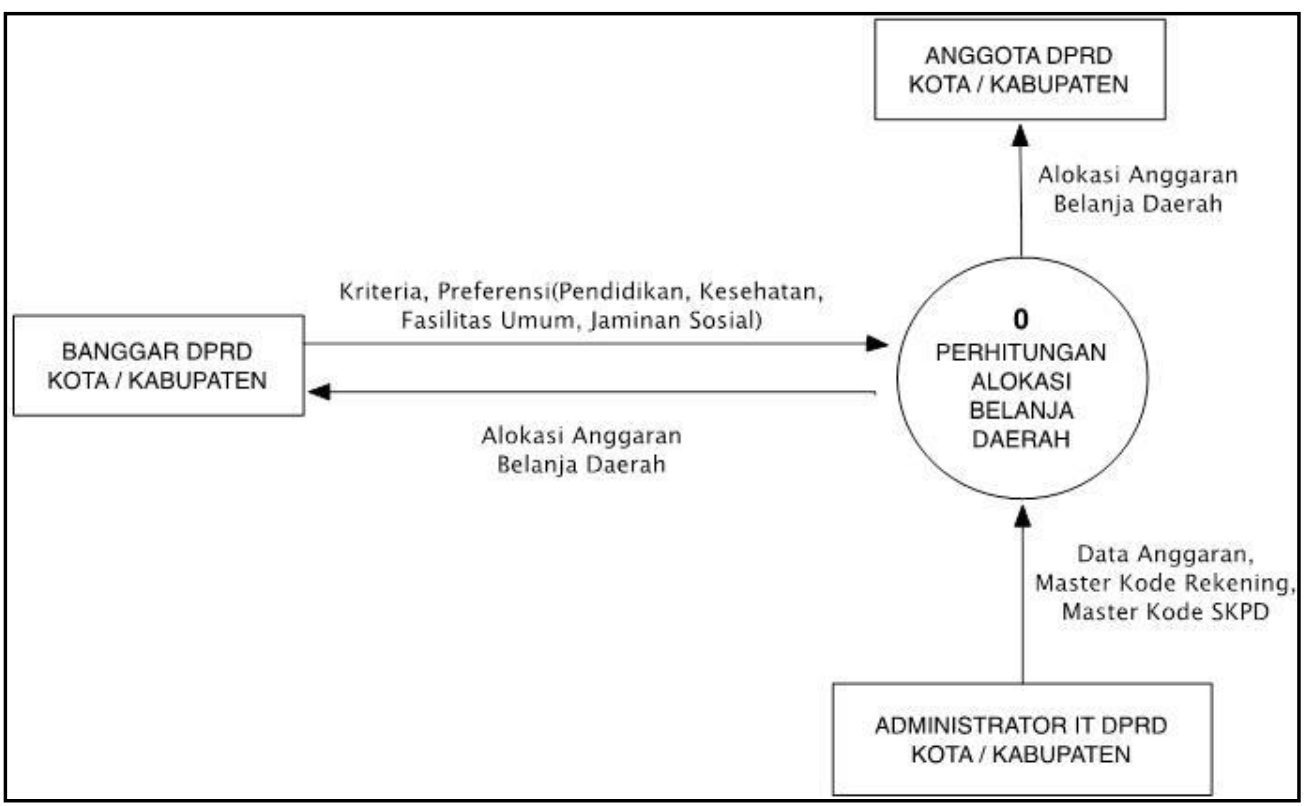

Figure 8 Data Flow Diagram Level 0

\section{DFD Level 1}

In data flow diagram level 1 as shown in Figure 9 below, it can be explained that in this system there are 5 pieces of process, they are: input process of budget data from APBD documents, input process of alternative preference values and criteria, process of calculating the value of Eigen Vectors for each alternative and criteria, Consistency test calculation process, and Calculation process of local budget allocation [3].

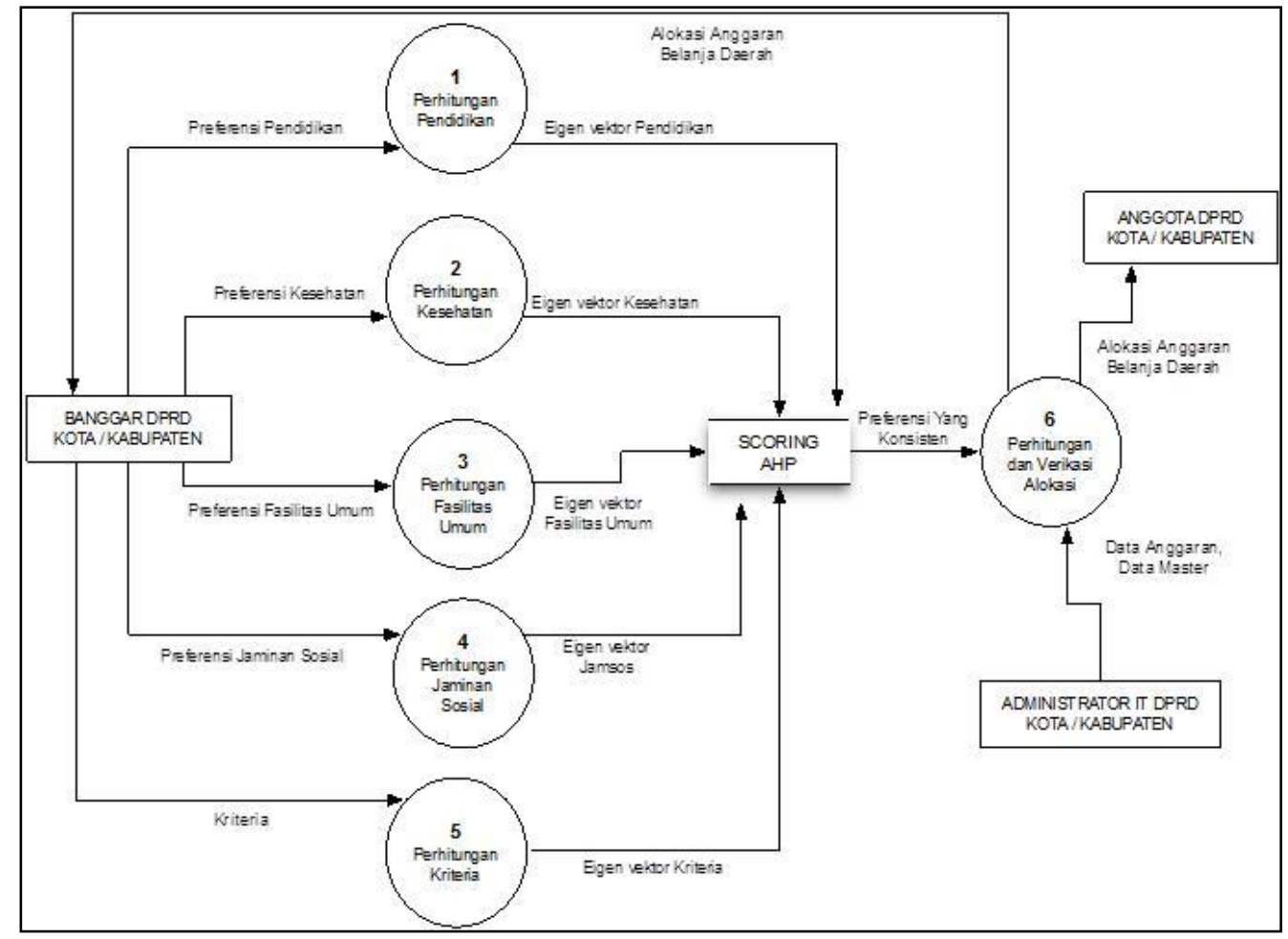

Figure 9 Data Flow Diagram Level 1 


\section{H. Input Features of APBD Analysis Information System}

From design results, application making up to testing system that has been done before, it required various features or menu information system that serves to provide access and control, there are various data processing budget of APBD. Thefour main features of the information system are Master Program Code of Activities, Master Code Account, Master Code Organization and Entry Data Budget
APBD. As for features explanation of this information system describe as follows:

\section{Master Program Code and Activities}

Serves to add, modify, or delete program and activity code, while the way of how to operate it, that is by Click Master menu, then click Activity Code. After that will appear as follows:

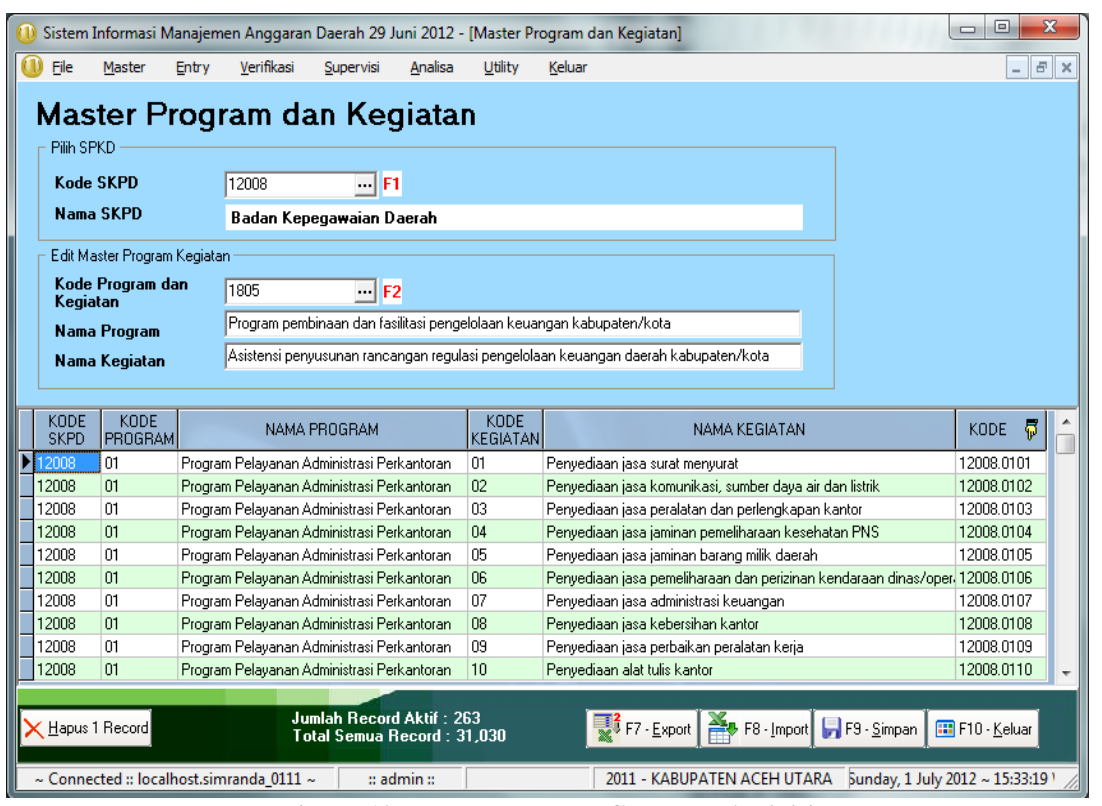

Figure 10 Master Program Code and Activities

\section{Master Account Code}

Serves to add, change, or delete code and account name.
The way of how operate it, by click master menu, and then click account code, after that will appear as follows:

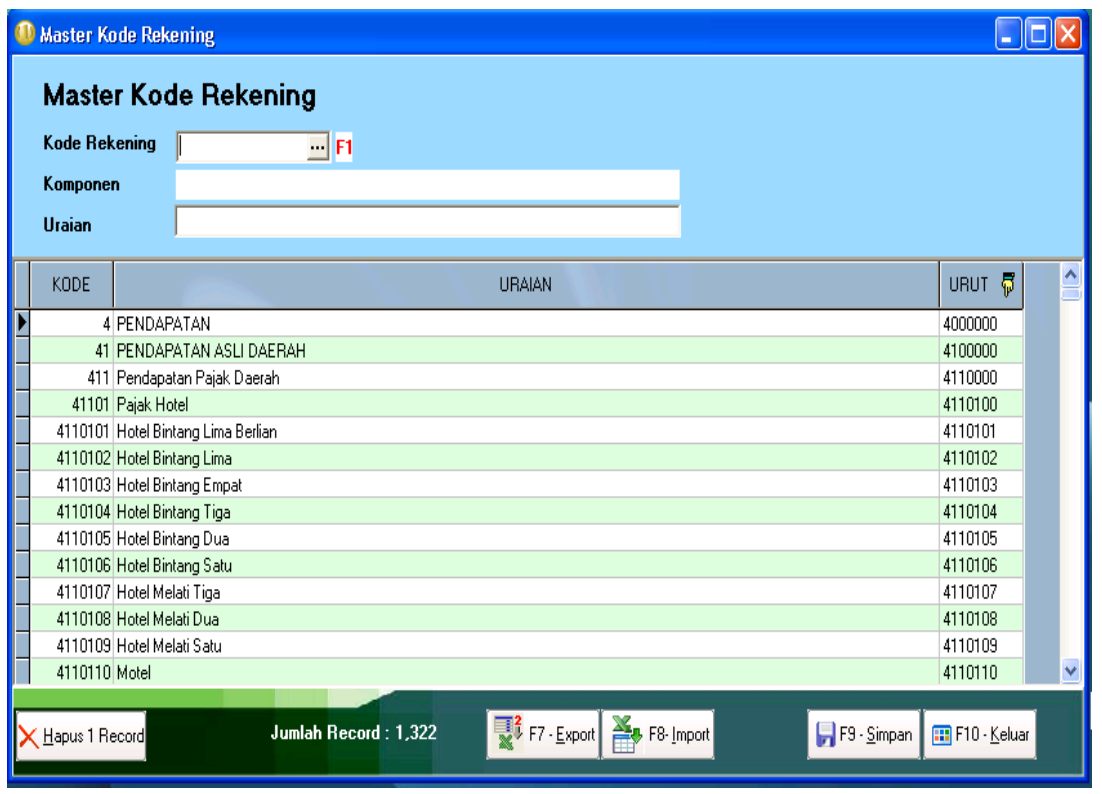

Figure 11 Master Account Code 


\section{Master Organization Code}

Serves to add, modify, or delete code and name of organization. The way how to operate it, by click master menu, then click organization code, after that it will appear as follows

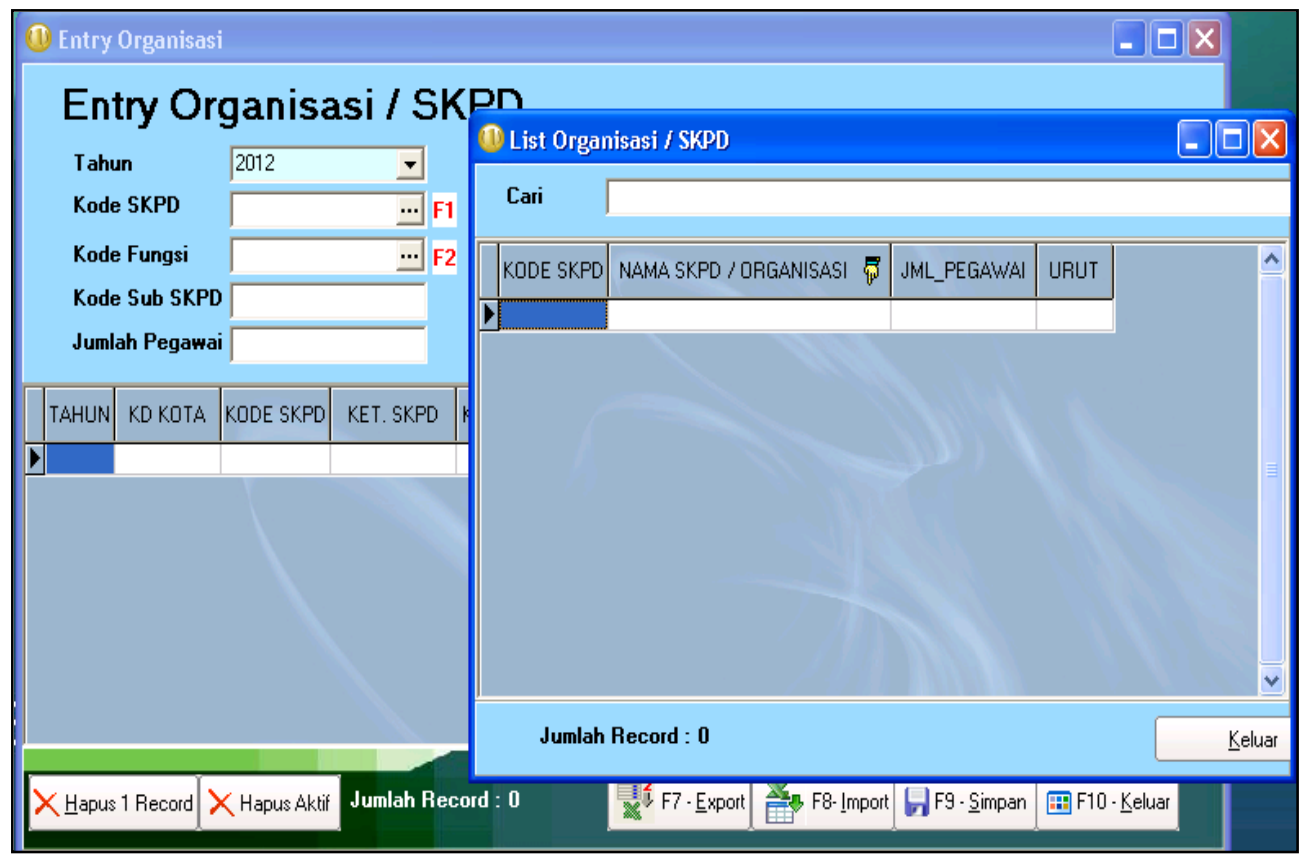

Figure 12 Master Organization Code

\section{Entry of Budget Data}

Data entry is an application feature that plays a very important role, because on this data entry menu, budget data derived from printed APBD documents converted into digital data.

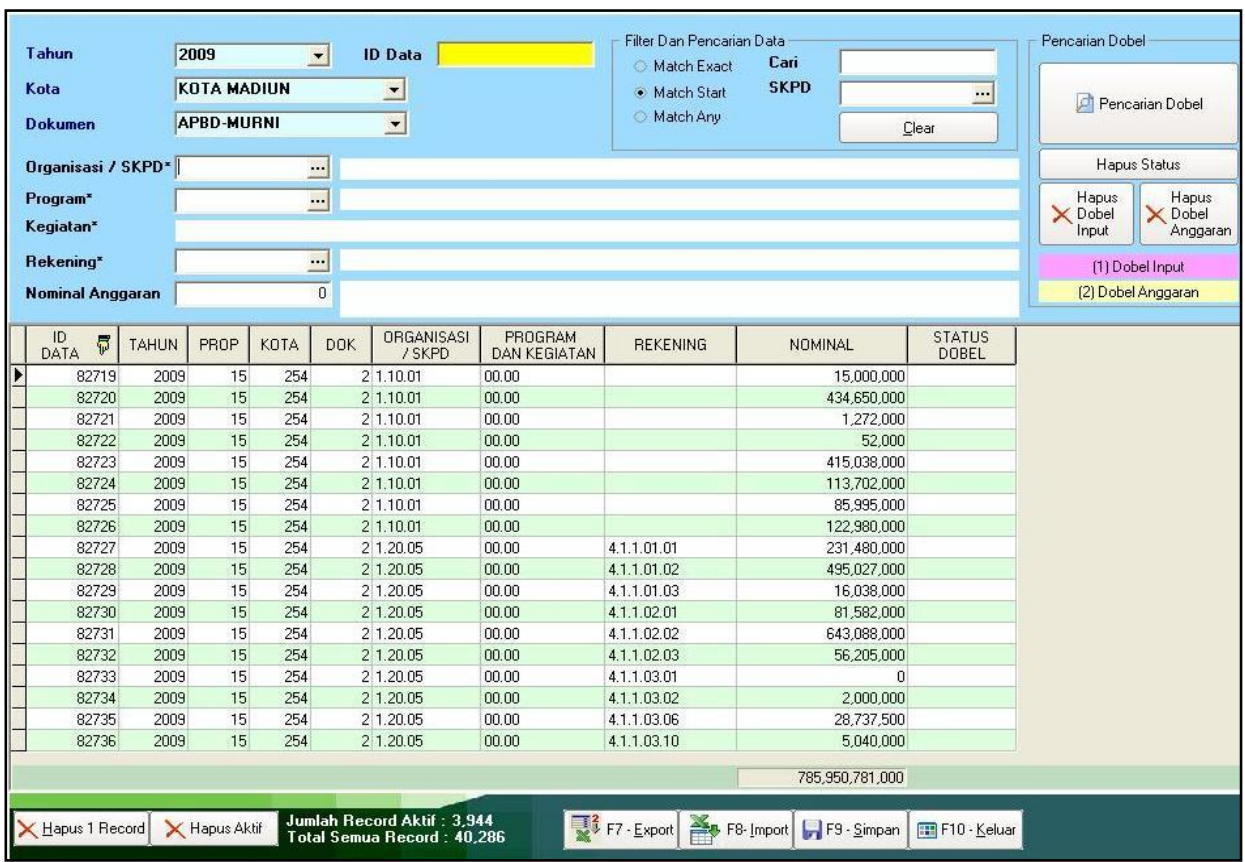

Figure 13 Entry of Budget Data

Feature also works for data budget verification as it comes with some facilities for change, deletion, search and also export-import of budget data that have been stored in budget database.

\section{Output Features of APBD Information System Analysis}

Output of this information system facilitates various forms of data presentation and information that makes it is easy to do analysis, they are as follows: 


\section{Local Revenue Analysis}

The output of this income analysis can be form in table by comparing budget allocation over last 5 years used to analyze development trend of budget allocations, whether the trend is decreasing or vice versa.

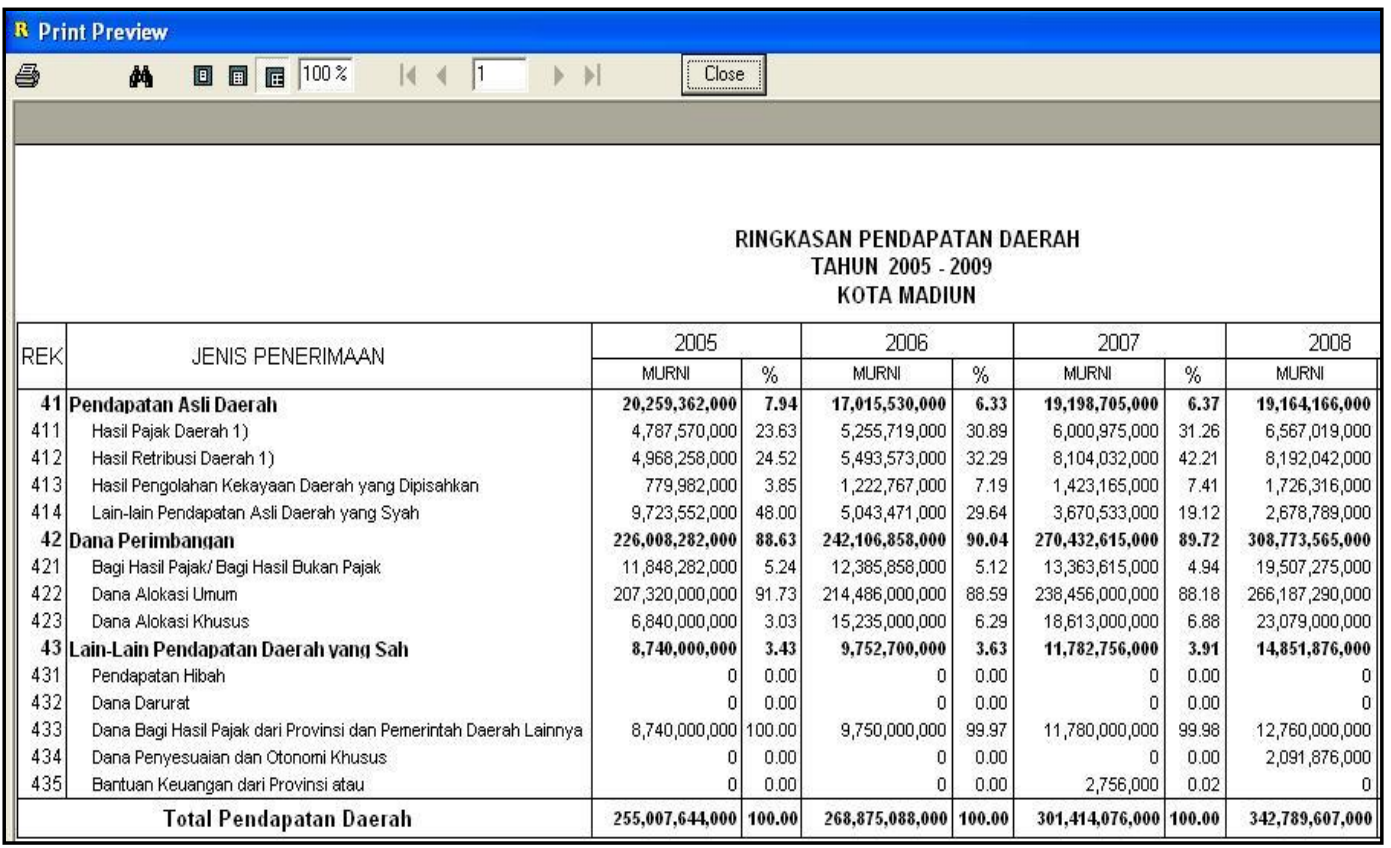

Figure 14 Table of Local Revenue Summary

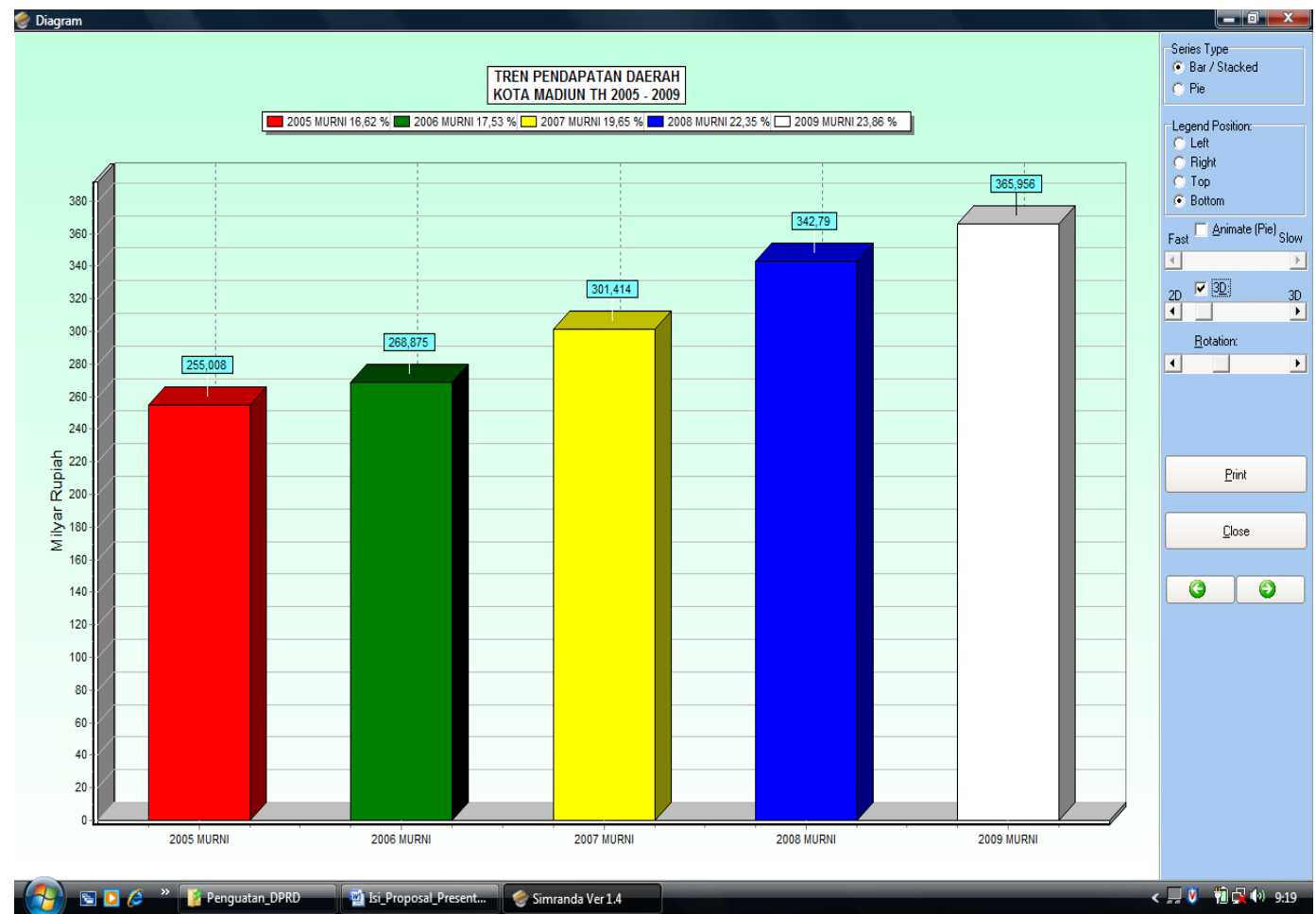

Figure 15 Bar Chart of Local Revenue Summary

\section{Analysis of Regional Expenditure}

This regional expenditure analysis serves to display output of regional spending analysis based on groups, types, objects and details of budget allocations that can be displayed in tables and graphs. With this facility, it will be able to analyze regional spending performance based on account code so that will be able to know about distribution and allocation of local expenditure in detail. It can also provide comparison of local expenditure allocation for the last 5 years. 


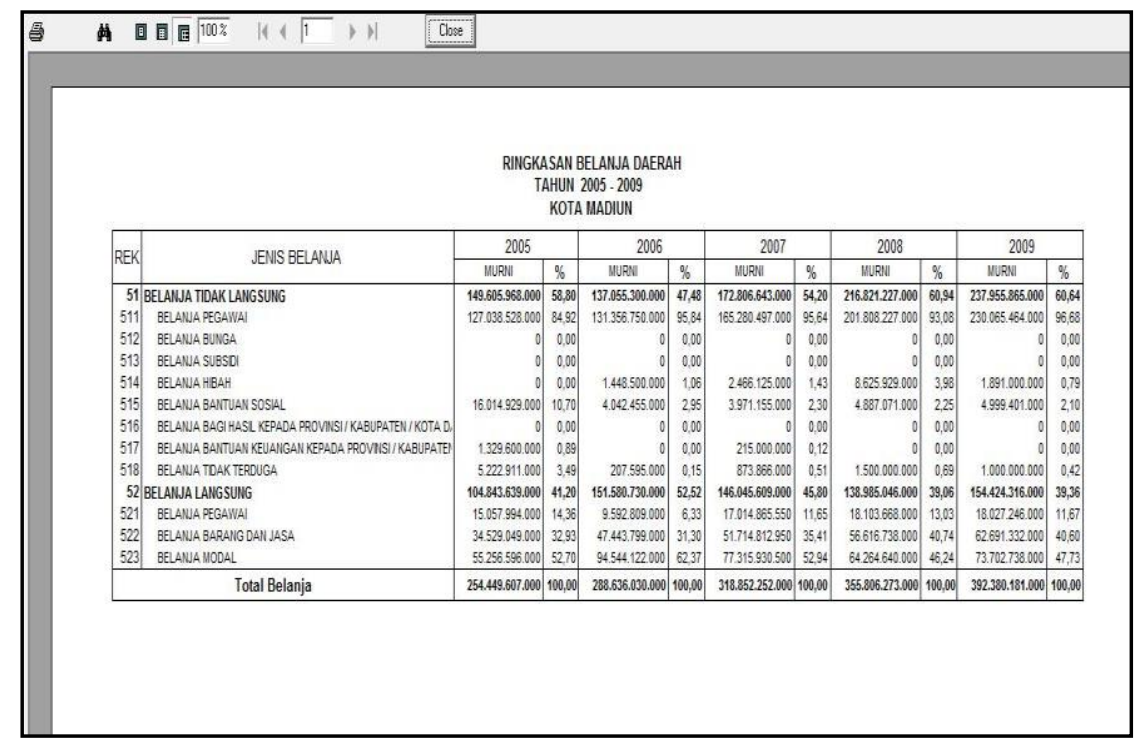

Figure 16 table of Regional Expenditure Summary
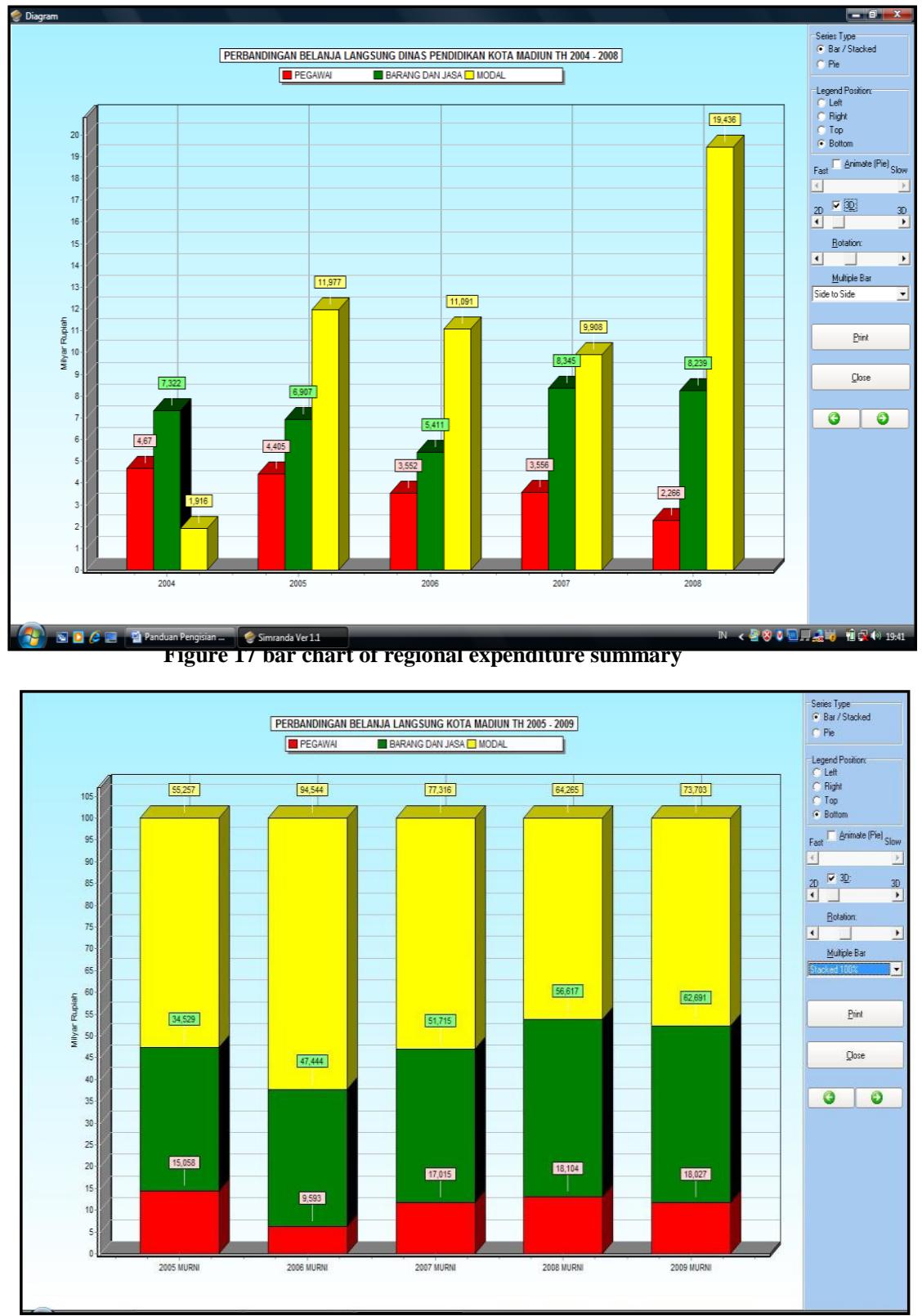

Figure 18 bar chart of regional expenditure summary 


\section{CONCLUSIONS AND RECOMMENDATIONS}

Based on formulation of the problem, system requirement analysis, design and testing system in which of APBD information systems application analysis has produced expected output then it can be concluded that:

1) APBD Information System Application has been able to facilitate process of digitization (over the media) or documentation of APBD budget data and other related data which then processed into information or knowledge and produce output in visualization form of clustering analysis or comparison analysis proportion of budget allocation by year budget, city / regency, organizational code, revenue account code, shopping account code, finance account code, program account code, activity account code, bill account code, group code, type code, object code, object description code and nominal budget. Where this cluster visualization will be valuable information and knowledge for strengthening literacy capacity, transparency and analysis in local regulation of APBD deliberation and stipulation process that transparent and accountable.

2) This APBD Information System Application in future will be a tool for members of City / Regency Parliament (DPRD) throughout Indonesia in running its budget functions quickly, accurately, effectively and efficiently.

Based on conclusions above, suggestions or recommendations for follow-up plan of this information system development are as follows:

1) Conduct a research that focuses on adoption factors valuation of APBD analysis information system using Technology Acceptance Model (TAM) to identify various forms that influence users in using APBD analysis information system. While benefit of this research results is; it can be an input in improving, upgrading and developing features of existing information systems APBD analysis.

2) Conducting research and developing application of Analysis Information Systems APBD-based Website, with aim to improve coverage of utilization and ease of user access throughout city and regency.

3) Conducting research and development of Information System Analysis APBD applications based on Mobile (Android), with aim to improve coverage of utilization and ease of user access throughout the city and district.

4) Conducting research and developing an accountability expert system of APBD that is a system which has capability in conducting consultation activities, diagnosis / identification and recommendations of effective and efficient APBD accountability management.

5) Conducting research and developing a budget accountability support system APBD that is a system which has capability to determine composition, proportion and distribution of accountably APBD allocations accurately, effectively and efficiently.

6) Processing APBD Information Systems Analysis to Ministry of Justice and Human Rights Republic of Indonesia, Director General of Intellectual Property to obtain Records Letter of Creation in Protection of Copyright Framework in Field of Science, Art and Literature Under Law No. 28 of 2014 About Copyright.

7) Processing Patent Algorithm Draft of APBD Information Systems Analysis to Ministry of Justice and Human Rights of Republic Indonesia, Director General of Intellectual Property to obtain a Patent Certificate Under Republic Indonesia Law Number 13 Year 2016 About Patent.

\section{ACKNOWLEDGEMENT}

Indonesian Research Technology dan High Education Ministry.

Research Institution and Civil Service of Kahuripan University Kediri.

Research Institution and Civil Service of Merdeka Madiun University.

\section{REFERENCES}

[1] Peraturan Menteri Dalam Negeri Nomor 13 Tahun 2006 Tentang Pedoman Pengelolaan Keuangan Daerah

[2] Peraturan Menteri Dalam Negeri Nomor 59 Tahun 2007 Tentang Perubahan Atas Peraturan Menteri Dalam Negeri Nomor 13 Tahun 2006 Tentang Pedoman Pengelolaan Keuangan Daerah

[3] Widjiseno, Assistriadi., 2013, Perancangan Dan Pembuatan Aplikasi Penentuan Proporsi Alokasi Anggaran Belanja Daerah BagiAnggota DPRD Kota/Kabupaten, Teknobisnis, Prosiding Seminar Nasional ManajemenTeknologi XVIII Program Studi MMT-ITS, Surabaya 27 Juli 2013.

[4] Widjiseno, Assistriadi., 2017, TecnoscienzaUniversitas Kahuripan Kediri Volume 1 No 2 April 2017 ISSN : 2541-3295, Penentuan Proporsi Alokasi Anggaran Pada Dokumen APBD Kota/Kabupaten Dengan Menggunakan Metode AHP

[5] Research Triangle Institute International, 2009, Local Governance Support Program Final Report, USAID (United States Agency International Development) LGSP (Local Governance Support Program)

[6] Legislative Strengthening Team, 2009, Analisis APBD untuk Anggota DPRD, USAID (United States Agency International Development) LGSP (Local Governance Support Program)

[7] Civil Society Strengthening Team, 2008, Partisipasi Organisasi Masyarakat Dalam Proses Perencanaan Dan Penganggaran,USAID (United States Agency International Development) LGSP (Local Governance Support Program) 